日臨外会誌 $65(3), 837-841,2004$

症例

内ヘルニア 6 例の検討

仙台赤十字病院外科

中川国利遠藤公人 鈴木幸正桃野哲

過去 20 年間で経験した内へルニア 6 例を，踇床的に検討したので報告する．内訳は傍 十二指腸へルニア 3 例, 小腸間膜裂孔へルニア, 盲腸後简へルニア, S 状結腸間膜へル二 アが各 1 例であった，年齢は18歳から79葴（平均58.0歳）で，男性 4 例㧍よび女性 2 例 であった。イレウス症状は 3 例で認めた。一方, 傍十二指腸へルニア3 例ではイレウス 症状はなく，いずれも結腸癌の開腹時に初めて内へルニアと診断された. 全例て内へル ニアの術前診断はできなかったが，CT 検查を術前に施行した 5 例では内へルニアを示 唆する所見が描出されていた．手術は脱出した腸管を全例で整復し，壊死を認めた 2 例 では腸管を切除した。へルニア䧶は 2 例で閉鎖，1 例で開放し，傍十二指腸へルニアの 3 例では結腸切除により消失した，予後はいずれも良好であった。内へルニアの術前診 断は困難とされているが，本疾患を念頭に置いて CT 検査などの画像診断を行う必要が ある.

索引用語：内ヘルニア, 傍十二指腸ヘルニア, イレウス

\section{はじめに}

内ヘルニアは比較的稀な疾患であり，イレウスとし て緊急手術をされることが多く, 術前診断は困難とさ れている(12).われわれは過去20年間で経験した内へル ニア 6 例について, 術前検查を中心に若干の文献的考 察を加えて報告する。

\section{対 象}

過去 20 年間に当科で開腹手術を施行した 7,355 例の うち, 手術時に内へルニアと診断された 6 例を対象と して種々の臨床的検徱を行った。なお同期間に手術を 施行されたイレウス症例は232例であった.内へルニア の内訳は，傍十二指腸ヘルニア 3 例，小腸間膜裂孔へ ルニア, 旨腸後窝へルニア, $\mathrm{S}$ 状結腸間膜ヘルニアが各 1 例であった。

\section{結果}

1. 年齢・性別

年齢は18歳から79歳, 平均58.0葴であった（表 1 ）。 また性別は，男性 4 例および女性 2 例であった。

2、主訴

2003年 9 月17日受付 2003年12月 9 日採用 〈所属施設住所〉

干982-8501 仙台市太白区八木山本町 2-43-3
主訴は，腹痛 4 例抢よび無症状 2 例であった。とく に症例 $4,5,6$ の 3 例では腹痛が著明で, 嘔気, 嘔 吐などのイレウス症状を伴い, 腹部は膨満していた。 また症例 2 の右下腹部痛は軽度で, 右下腹部に腫㿔を 触知した，無症状の 2 例は，健診時の便潜血反㐫が陽 性であった。

3 . 病遖期間

イレウス症状を呈した症例 $4 ， 5$ では, 発症から手

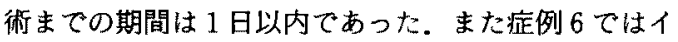
レウス管留置による保存的療法でも症状の改善を認め なかったため, 発症から13日目に手術を施行した。一 方, 軽い右下腹部痛を主訴とした症例 2 の病悩期間は 1カ月間であった。

\section{4. 術前検查}

腹部単純 $\mathrm{X}$ 線写真：症例 $1 ， 2$ では右上腹部に, 症 例 3 では左上腹部に小腸ガスの集積像を認めたが, 術 前には小腸ガスの集積像を指摘できなかった（表2）。 また症例 4，5，6では， niveauを認めた。

腹部 CT 検査：CT 検查は，全身状態が不良で緊急 手術を施行した症例 4 を除く 5 例で施行した。症例 1 , 2 では右上腹部に(図 1，2）, 症例 3 では左上腹部に 小腸塊を認めた(図 3 )。また症例 5 では盲晹の背側に 拡張した小腸を認め, 盲腸を内側に圧排していた（図 
表 1 内ヘルニア症例

\begin{tabular}{|c|c|c|c|c|c|}
\hline 症例 & 年齢 & 性別 & 主訴 & 病偪期間 & 腹部所見 \\
\hline 1 & 58 & 女 & 無 & 無 & 無 \\
\hline 2 & 79 & 女 & 右下腹部痛 & 1 カ月 & 腫裙触知 \\
\hline 3 & 57 & 男 & 無 & 無 & 無 \\
\hline 4 & 18 & 男 & 腹痛 & 1 日 & 腹部朧満 \\
\hline 5 & 68 & 男 & 右下腹部痛 & 1 日 & 腹部膨满 \\
\hline 6 & 68 & 男 & 左下腹部痛 & 13日 & 腹部脭满 \\
\hline
\end{tabular}

表 2 術前検査と術前診断

\begin{tabular}{|c|c|c|c|c|}
\hline 症例 & 腹部単純X線 & CT検查 & 消化管造影 & 術前診断 \\
\hline 1 & 小腸ガス集積 & 小腸塊 & 結腸压排 & 上行結腸癌 \\
\hline 2 & 小腸カス集積 & 小腸塊 & 結腸死排 & 上行結腸帠 \\
\hline 3 & 小腸ガス集棹 & 小腸塊 & 結腸圧排 & 下行結腸癌 \\
\hline 4 & niveau & 未施行 & 末施行 & イレウス \\
\hline 5 & niveau & 盲腸正排 & 末施行 & イレウス \\
\hline 6 & niveau & 小腸閉塞 & 小腸門塞 & イレウス \\
\hline
\end{tabular}

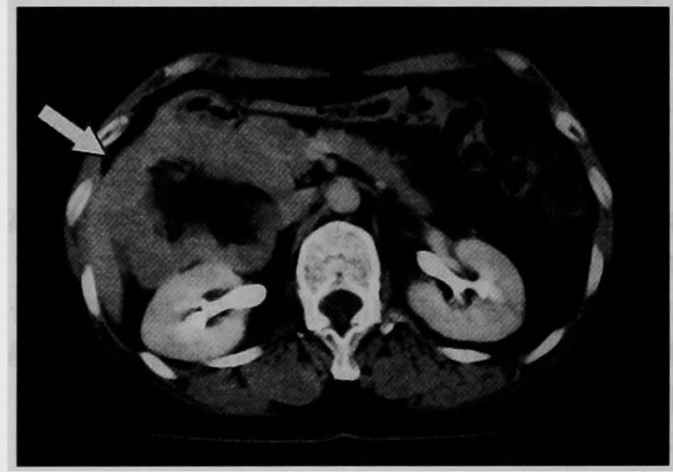

図 1 症例 1 ：腹部 CT 検查では, 右上腹部に小腸塊(矢 印）を認めた。

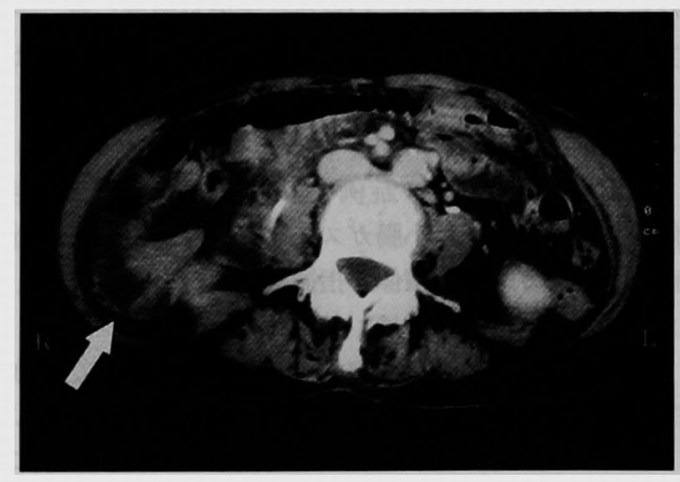

図 2 症例 2 : 腹部 CT 検査では, 右腹側部に小腸（矢 印）を認めた。

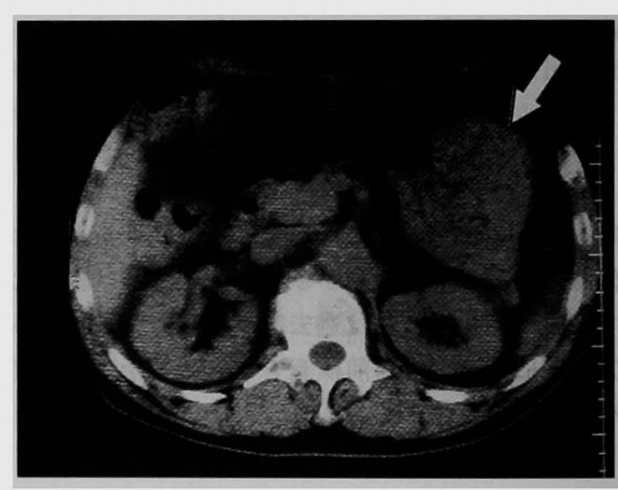

図 3 症例 3 ：腹部 CT 検査では, 左上腹部に小腸 塊（矢印）を認めた。

4 ). 症例 6 ではイレウス管からの小腸造影を併用して CT 検查を行い，イレウス管の先端に小腸の閉塞を認 めた (図5).

消化管造影検査：症例 $1 ， 2 ， 3$ では注腸造影で上 行結腸および下行結腸にそれぞれ腫瘤を認め, 内視鏡 下の生検で癌と診断した. なお術後の検討では, 症例 1,2 では上行結腸の外側に小腸ガス像が存在し, 上 行結腸は内側へ圧排されていた(図6). 症例 6 ではイ レウス管からの小腸造影で, 左下腹部のイレウス管先 端に先細り状の小腸閉塞を認めた。

以上の術前検查から, 症例 $1,2,3$ は結腸癌, およ び他の 3 例はイレウスと術前診断して手術を施行した。 


\section{5. 手術所見と術式}

症例 1 , 2では十二指腸上行部と空腸は上腸間膜動 静脈の後部で右側に走行し, 後腹膜腔に嵌入していた

（表 3 ），嵌入腸管に循環障害を認めなかったため, へ ルニア襄外へ整復すると共に上行結腸癌に対する結腸 右半切除術を施行した。また症例 3 では Treitz 䩓帯左

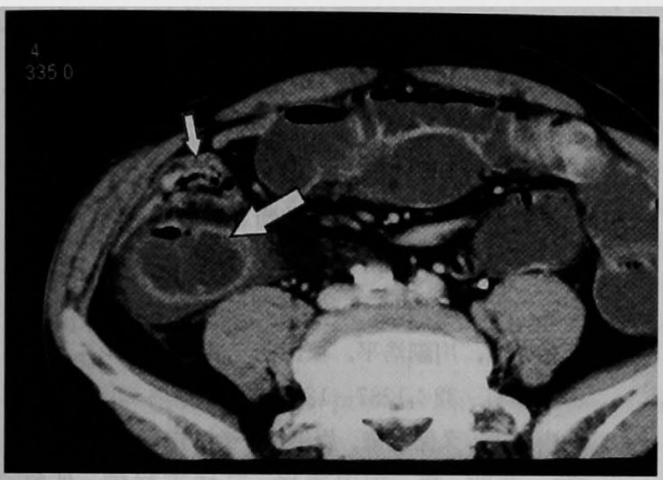

图 4 症例 5 : 腹部 CT 検査では盲腸 (小矢印) の背側に 拡張した小腸 (大矢印) を認め，盲腸を内腹側に圧排し ていた.

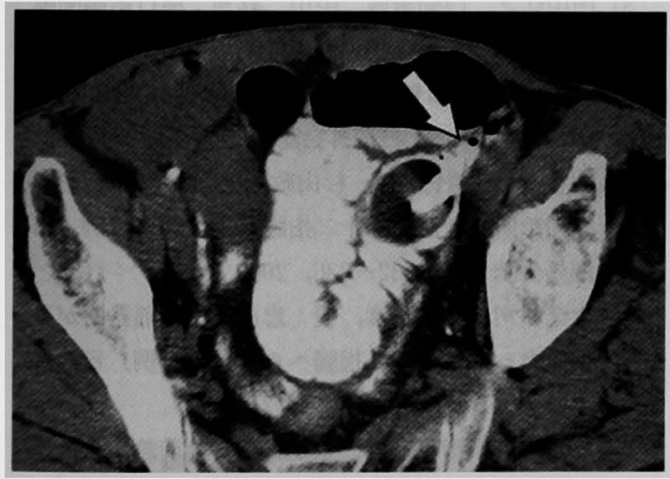

图 5 症例 6 ：小腸造影を併用した CT 検査では, イレウ ス管の先端に小腸の閉塞（矢印）を認めた。
側の上十二指腸窩にヘルニア門を認め，空腸の一部が 嵌入していた。循環障害を認めなかったためへルニア 桽外へ整復すると共に，下行結腸癌に対する結腸左半 切除術を施行した，症例 4 では回腸が小腸間膜裂孔に 嵌入していたが, 循環障害を認めなかったため整復し， ヘルニア門を縫合閉鎖した。症例 5 では盲腸後窩に回 腸が炭入し，盲腸を腹側に圧排していた，循環障害を 認めた嵌入腸管を切除すると共に，へルニア門を形成 する後腹膜を切開した，症例 6 では $\mathrm{S}$ 状結腸間膜右葉 に欠損を認め, 回腸が嵌入していた。循環障害を認め た嵌入腸管を切除すると共に，ヘルニア門を縫合閉鎖 した。

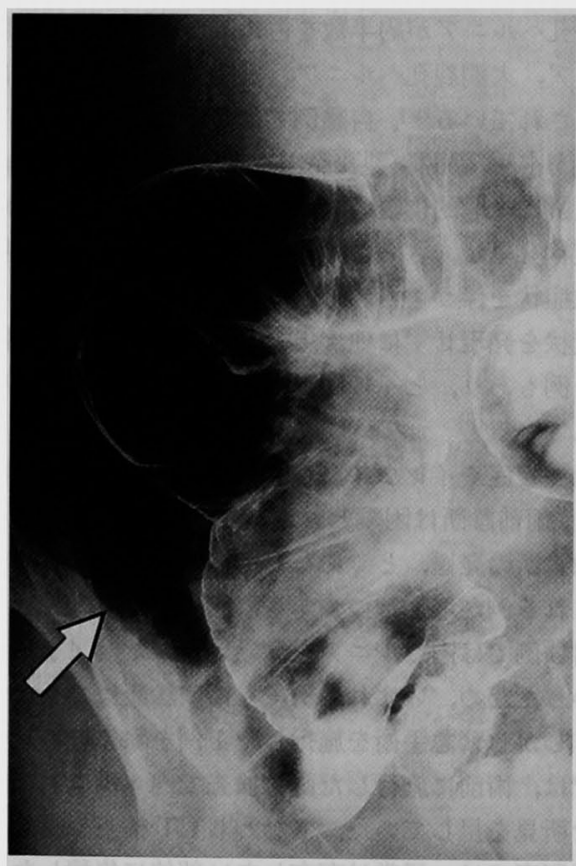

图 6 症例 2 ：注腸造影検査では，上行結腸の外 側に小腸ガス像（矢印）が存在し，上行結腸は 内側へ圧排されていた。

表 3 手術所見と術式

\begin{tabular}{clclc}
\hline 症例 & \multicolumn{1}{c}{ 手術所見 } & 腸壞死 & \multicolumn{1}{c}{ 術式 } & 術後経過 \\
\hline 1 & 右傍十二指腸ヘルニア & 無 & 結腸右半切除 & 良好 \\
2 & 右傍十二指腸ヘルニア & 無 & 結腸右半切除 & 良好 \\
3 & 左傍十二指腸ヘルニア & 無 & 結腸左半切除 & 良好 \\
4 & 小腸間膜裂孔ヘルニア & 無 & 整復・閉銷 & 良好 \\
5 & 盲腸後窝ヘルニア & 有 & 回腸切除・開放 & 良好 \\
6 & S状結腸間膜ヘルニア & 有 & 回腸切除・閉鎖 & 良好 \\
\hline
\end{tabular}




\section{6. 術後経過}

術後の経過はいずれも良好で, 特別な偶発症は生じ なかった。

\section{考 察}

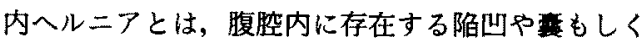
岋裂孔に腹腔内臟器の一部が嵌入した病態, または先 天的な晹間膜や大網の裂孔に腹涳内臓器が嵌入した病 態である ${ }^{122}$.

内へルニアは比較的稀な疾患であり，本邦における 頻度はイレウス手術症例の0.5 1.2\%とされてい る3). 当科では開腹手術を施行した7,355例中 6 例 (0.08\%)であった。またイレウスで手術を施行した 232 例中 3 例 $(1.29 \%)$ であった。文献上, 頻度は腸間 膜裂孔ヘルニアが約半数を占め, ついで傍十二指腸へ ルニア, 大網裂孔ヘルニア, 盲腸窝へルニアの順に多 いとされている122. 自験例では傍十二指腸へルニアが 半数を占め, 腸間膜裂孔へルニアは 1 例のみであった。 主訴は一般的に腹痛, 嶇吐, 腹部膨満などのイレウ ス症状を呈し, さらに腸管の循環障害が生じると腹膜 刺激症状を伴うとされている(12). しかし自験例のごと く症状を発現せずに他疾患の開腹時や剖検時に誩断さ れる例もあり，とくに傍十二指腸へルニアでは多いと されている゙.

急性腹症やイレウスとして緊急手術を行われる例が 多く,術前診断は困難とされてきだー31.しかし種々の

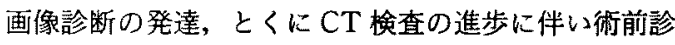
断される例が增加しつつあるがー9!.

自験例では内ヘルニアを念頭に置いた検討をしてい なかったため,いずれの例でも術前診断はできなかっ た.しかし緊急手術を施行した 1 例を除く他の5 例全 例では, 術前に施行した画像検查で内へルニアの特街 的な所見を呈していた。すなわち CT 㭘査や腹部単純 X線写真では, 通常は存在しない部位に集積した小腸 が存在し，周囲の腸管を圧排していた。また消化管造 影検査でも，集積した小腸による周囲腸管の圧排像を
呈していた。内ヘルニアの存在を常に認識して, 画像 診断を行う必要性を痛感させられた。

治療は基本的には手術が必要で，族入した腸管を整 復し、ヘルニア門の閉鎖もしくは開放を行う ${ }^{122}$. また 腸管に壊死を認めた場合には，腸切除を行う必要があ る.

\section{おわりに}

内ヘルニア症例はイレウス症状を呈する例が多い が，無症状の例も存在する，術前診断は困難とされて きたが，本疾患を念頭に置いた画像診断を常に行うこ とにより診断が可能になると思われる。

\section{文献}

1）天野純治：内へルニアの診断と治療．草間 悟， 和田達厷隹，三枝正裕編，外科 $\mathrm{MOOK}, 52$ 巻，金原 出况, 東京, 1989, p85-96

2）遠藤 蕉, 川副浩平, 菰田研二他：内ヘルニア. 小児外科 $32: 1287-1293,2000$

3）池内隼次, 久保宏隆，岩㴊秀一他：内へルニア(能 頓)。草間 悟, 和田達雄, 三枝正裕編, 外科 MOOK，35巻，金原出版，東京，1984，p71-79

4) Khan MA, Lo AY, Vande DM : Paraduodenal hernia. Am Surg $64: 1218-1222,1998$

5）田中弘之, 臼間康博, 中川 昇他：横行結腸間膜 列孔へルニアの 1 例. 手㭪 $56: 127-131 ， 2002$

6）片柳 創, 大植雅之, 山口達郎他：S 状結腸間膜内 ヘルニアの1例. 日消外会誌 $36: 304-308,2003$

7）木暮道夫, 植竹正紀，杉山政則 : CT, 小腸造影て 術前猃断できた左傍十二指腸へルニアの1例．日 臨外会誌 $64: 332-336,2003$

8）大楽耕司, 岸川正彦, 榎 忠彦他: 術前診断が可

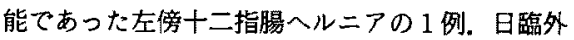
会誌 $64 ： 1903-1906,2003$

9）佐藤裕英，深谷 毅, 大中正光：術前診断の上, 待期的に手術を施行した盲腸筃へルニアの1例。 日臨外会誌 $63: 1026-1030,2002$ 


\title{
A CLINICAL STUDY OF SIX CASES OF INTERNAL HERNIA
}

\author{
Kunitoshi NAKAGAWA, Kojin ENDO, Yukimasa SUZUKI and Satoshi MOMONO \\ Department of Surgery, Sendai Red Cross Hospital
}

We report a clinical study of six cases of internal hernia experienced at the hospital in a recent 20year period. There were three cases of periduodenal hernia and each one case of hiatal hernia of the small bowel mesentery, subcecal fossa hernia, and hernia of the sigmoid mesentery, respectively. These patients were from 18 to 79 years old, with a mean of 58. 0 . The male-to-female ratio was 4 to 2 . Ileus symptoms were noted in three out of the six cases, while no ileus symptoms appeared in three cases of periduodenal hernia. All six cases were diagnosed at laparotomy for colonic cancer. Preoperative diagnosis could not be made in all six cases, but imaging findings suggestive of internal hernia were visualized in five of six cases in which CT scanning was carried out before surgery. Operative procedures included reduction of the herniated intestine in all six cases and intestinal resection in two cases in which intestinal necrosis was noted. Hernia sac was closed in two cases and was kept open in one; the sac disappeared by intestinal resection in the three periduodenal hernia. The prognosis was favorable in all cases.

It is thought that preoperative diagnosis of internal hernia is difficult, but we must keep the possibility of the disease in mind in carrying out imaging methods such as $\mathrm{CT}$. 